\title{
スペースシャトル搭載用大画面カメラ
}

\section{A Large Format Camera for Shuttle}

\author{
Frederick J. Doyle** \\ 訳者 村井俊 治
}

\begin{abstract}
概要 NASAは, 現在焦点距離 $30.5 \mathrm{~cm}$, フィルムサイズ $23 \mathrm{~cm} \times 46 \mathrm{~cm}$ 有する地形図作成用高性能カメラを製作中 である。このカメラは, スペースシャトルの初めの方の飛行に搭載される子定になっている。設計高度 $300 \mathrm{~km}$ 空から,

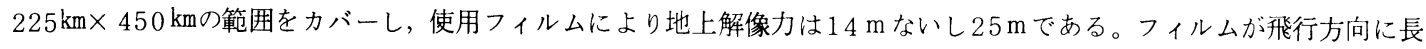
手サイズになるようにしてあるので，基線長／高度の比を 1.2 まで上げられる。したがって $20 \mathrm{~m}$ ない $30 \mathrm{~m} の$ 等高線間
\end{abstract} 隔の地形図の作成が可能である。

もし, 実験飛行から得られた写真が期待どおり良好な場合には, ぼ゙円軌道で自由飛行する宇宙船にこのカメラが搭載 され，何ケ月にもわたって撮影が行われる。フィルムはシャトルにより回収される。

ジェミニ計画で手持ちのハッセルブラッドカメラにより最初の宇宙写真撮影が行われた時から, 写真測量技術者は, 軌 道衛星により, 空中写真測量から宇宙写真測量へと理論を抗張できるものと考えていた。LANDSAT計画の広範な成功 にもかかわらず, 写真測量技術者は, LANDSAT の映像が低解像力でかつ実体視ができないために, 実体図化が不可能 であることに不満をもってきた。

1967 年の昔に, 国立科学アカデミーの『地球観測衛星の有効利用に関する委員会』は, 世界中の地形図作成が可能な カメラシステムの開発を答申した。この答申によれば, システムは標定のための地形闵用フレームカメラと, 平面的な詳 細図化のためのパノラマカメラで構成されていた。この方法の可能性を検討するために, アポロ 15 号, 16 号, 17 号に似 たようなシステムが導入され，月軌道で実験された。これらの写真の測定にもとずいて，月面上の点が三次元座標で 30 $\mathrm{m}$ の間隔の密度で標定され，2万 5 千分の 1 の縮尺のオルソフォトマップが作成された。このようなシステムが地球観測 軌道に採用されるよう何度か提案されながら, 種々の理由により，このシステムは実現されなかった。

\section{1. カメラの 設 計}

NAS A は現在スペースシャトルに搭載する機器と して大画面カメラ (Large Format Camera:LFC) を開発している。このカメラの諸元は以下のとおりで ある。

焦 点 距 離 $=30.5 \mathrm{~cm}$

* この論文は昭和 53 年 5 月 31 日に行われた国際写真測 量学会（I S P ）の第 1 部会の東京シンポジウムで発表 されたものである。

** 米国地質調查所

*** 東京大学生産技術研究所 IS P 第一部会 Sec ret a ry 「写真測量とリモートセンシング」Vol. 16, №4, 1977
フィルムサイズ $=23 \mathrm{~cm} \times 46 \mathrm{~cm}$

口 径 $=116.0$

カメラは，フィルムの長手サイズが飛行方向になる ように搭載される。

レンズは, 図1に示されるように, 9つの光学要素 のほかに, 周辺減光防止用のフィルタで構成されてい る。画面全体で最大 $15 \mu \mathrm{m}$ の歪があり, 中央の $23 \mathrm{~cm} \times$ $23 \mathrm{~cm}$ 範囲で $10 \mu \mathrm{m}$ 歪が生じる。このレンズは, $0.40 \mu \mathrm{m}$ から $0.90 \mu \mathrm{m}$ の波長の間で色補正がなされる。 レンズ中央に光学フィルタを挿入することができるよ うになっており，白黒フィルム，カラーフィルムおよ び赤外フィルムに対するカラーバランスが補正される。 これらのフィルタは外部からの指令によりモーターを 駆動させて変えることができる。このレンズは, ミリ 


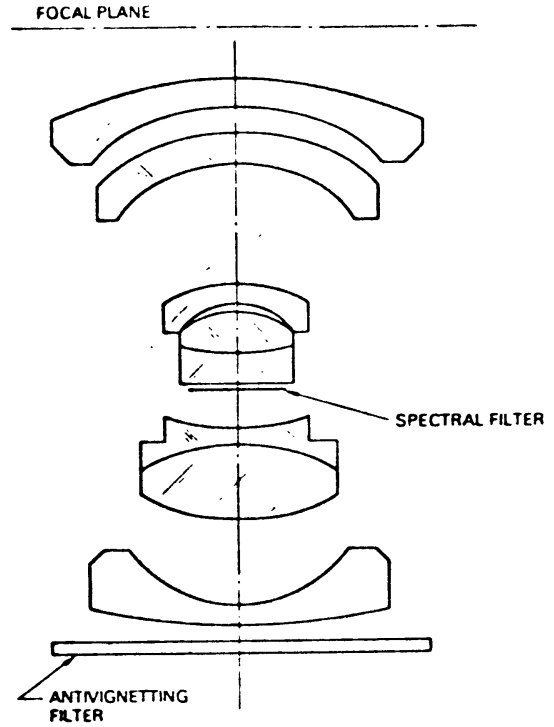

Fig. 1 LFC Lens Configuration

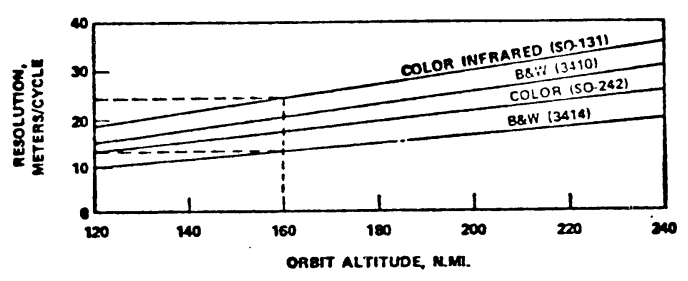

Fig. 2 Dynamic Ground Resolution at 2:1 Contrast

当り 80 本ペアーの解像力をもち, 周辺部でも最低ミリ 当り 50 本ペアーの解像力を有する。このレンズによる 地上解像力は図 2 に示される。通常運行高度 $300 \mathrm{~km}$ （160海里）に扔いて, 白黒フィルムで大体 $14 \mathrm{~m}$, 赤 外カラーフィルムで $25 \mathrm{~m}$ の地上解像力となる。この值 は写真解像力であって, LANDSAT のように光学一 電気システムで通常用いられる画素サイズの值でない ことに注意してほしい。14 m の写真解像力は, 画像上 で詳細が認識できる画素サイズで言えば， $6 \mathrm{~m}$ の画素 サイズに匹敵する。レンズの原型はすでに試作されて 検査されている。歪打よび解像力に関しては検証済み である。

レンズの中間に設けられるシャッターは，従来型の ものとほぶ同じで, 回転ディスク型か開閉ブレード型 である。高分解能の白黒フィルムおよびカラーフィル ムに露光を与えるにはシャッター速度を比較的低速に する必要がある。露光時間は, 0.006 秒から 0.024 秒 までの簌囲をとることができ，オペレータの指示また は露出計によって設定される。この露出計は $5{ }^{\circ}$ の視野

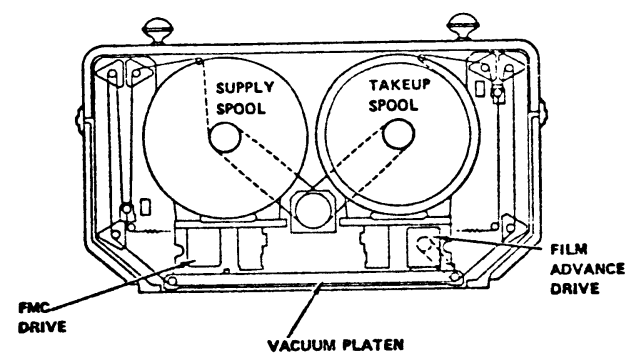

Fig. 3 LFC Film Magazine

角を有し, 露光前の 15 秒間の光量を積分する。この場 合, 雲, 雪, 太陽の鏡面光などの高反射光を無視する。 図 3 に示されるように, カメラには最大 $2,000 \mathrm{~m} の$ フィルム，4,000画面分のマガジンが取付けられてい る。この多量のフィルムをかかえるフィルムスプール はきわめて重くなるので, 始動および停止の際の振動 を防ぐために撮影中は連続的に回転させる必要がある。 そのため, フィルム送り側とフィルム巻取側の両方に 軽量の遊びのローラーを備えつけてカメラの作動中に フィルムが直接スプールにカが伝わらないようにする。 レンズコーンとカメラ後部の間に負圧の圧力差をかけ てフィルムが圧定板に密着するように圧定する。圧力 差を作るのにチッ素ガスが用いられる。これにより， 静電気の発生とフィルムの破損を防止できる。フィル ムが圧定板に密着している間，この圧定板は前動ぶれ 補整 (Forword Motion Compensation: FMC) のために飛行方向に動くことになっている。FMCの 範囲は, 秒当り 0.010 ラジアンから 0.045 ラジァンの 間であり, これは, スペースシャトルの通常運行高度 に対して適切な值となっている。この FMCのために, 高解像フィルムに必要なだけ露光時間を長くすること ができる。圧定板には $5 \mathrm{~cm}$ 間隔のレゾーが切られてい る。このレジーは, $0.05 \mathrm{~mm}$ の印で, 圧定板のうし ろから発光ダイオードで照射されている。レジーは指 令により点滅ができるようになっている。おそらく， 最初と最後の方の写真だけレゾーが同時撮影される予 定である。

図 4 は, 写真の画枠を示している。中央の上下辺と 左右辺に設けられた指標により主点の位置が決定され る。中央の $23 \mathrm{~cm} \times 23 \mathrm{~cm} の 4$ 隅にも指標が設けられる。 注記データとして撮影時刻, 軌道, 写真番号がうつし 込まれる。 


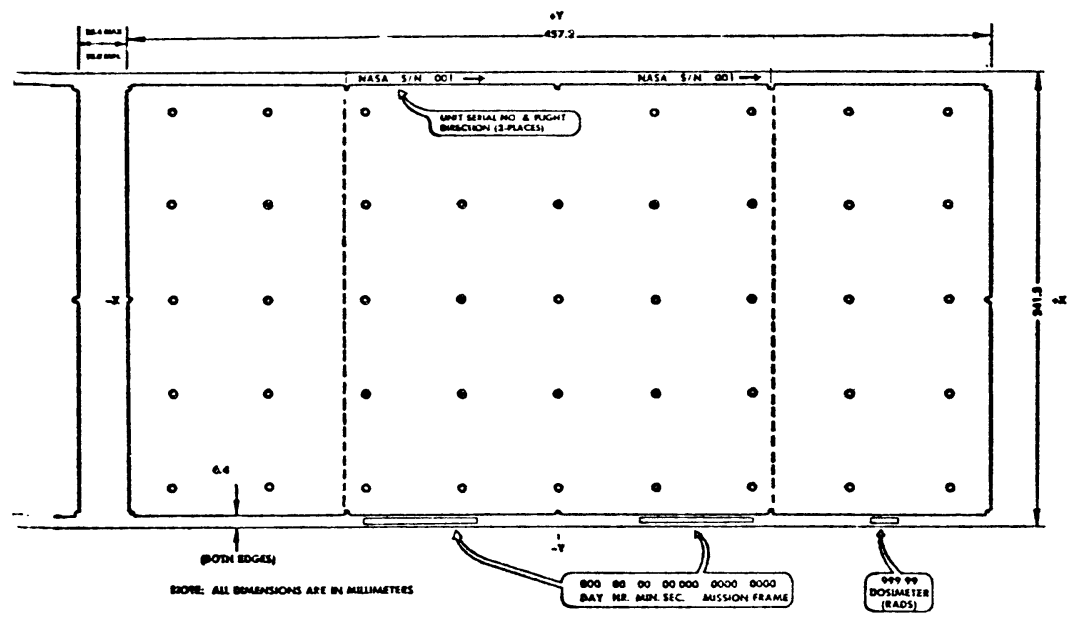

Fig. 4 Focal Plane Fiducials and Reseau

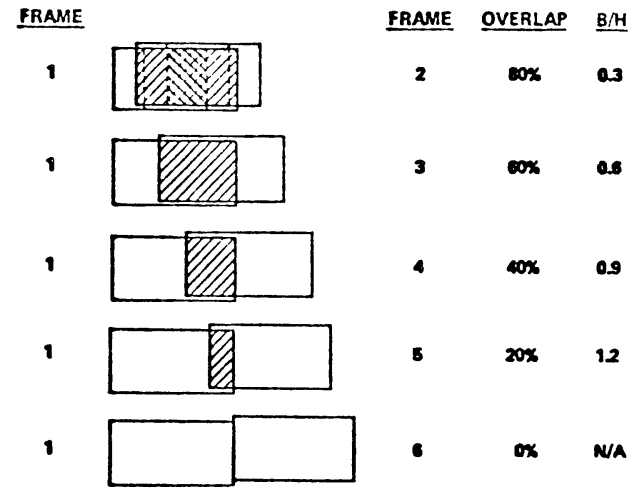

Fig. 5 B/H Ratios at $80 \%$ Overlap

\section{2. カメラの操作}

通常は，80\%のオーバーラップをとる。指令により $60 \%$ おび $10 \%$ にすることもできる。罒 5 に示され るように，オーバーラップの選択によって，基線／高 度比を 0.3 から 1.2 にすることができる。全体で 80 $\%$ オーバーラップの場合, 中央部の $23 \mathrm{~cm} \times 23 \mathrm{~cm}$ については $60 \%$ オーバーラップとなり，B／H比は 0.3 となる。焦点距離が $30.5 \mathrm{~cm}$ のカメラで撮影された 空中写真を扱える写真測量困化機なら，この中央部の オーバーラップ部の図化が可能である。最大の B / $\mathrm{H}$ 比を有するオーバーラップ写真の利点は, 写真測量困 化機を用いる際に主点の位惪が $23 \mathrm{~cm} \times 23 \mathrm{~cm}$ の゙イヤ ポジの中心からはるかに離れていることである。

図 6 に示されるように, 軌道高度に対して地上の撮

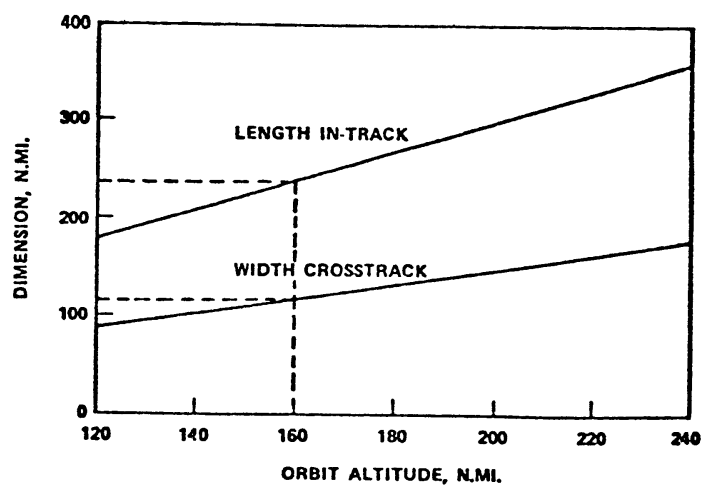

Fig. 6 Terrain Coverage Dimensions

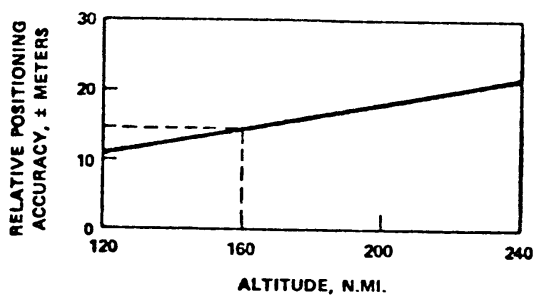

Fig. 7 Position Accuracy

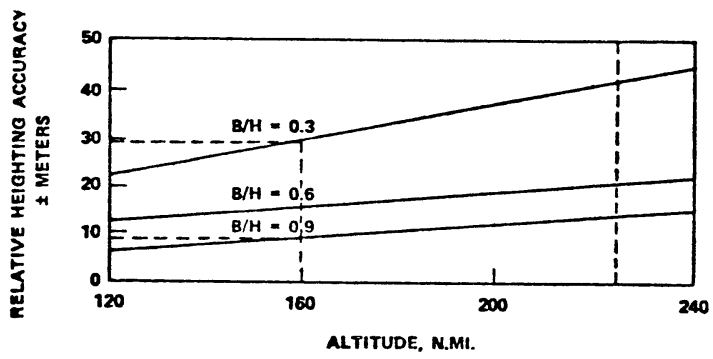

Fig. 8 Elevation Accuracy 
影範囲がきわめて広い。たとえば， $300 \mathrm{~km} の$ 通常高度 の場合で，撮影される地上の範囲は $225 \mathrm{~km} \times 450 \mathrm{~km}$ ( 120 カイリ $\times 240$ カイリ) である。

図 7 は，写真面上で $0.015 \mathrm{~mm}$ の精度を持たすことが できると仮定した場合の位置精度を示している。300 $\mathrm{km}$ の高度で, 地上 $15 \mathrm{~m}$ に相当する精度であり, 縮尺 1 ：50,000の地図作成が可能となる。図 8 は, 種々の $\mathrm{B} / \mathrm{H}$ 比に対する高さの測定の精度を示している。300 $\mathrm{km}$ の高度の場合で, $10 \mathrm{~m}$ より良い高さの精度を有して いる。これは， $30 \mathrm{~m}$ の等高線間隔の地図作成が可能な ことを示している。

\section{3. 宇宙船への搭載}

カメラは最初に, 図 9 に示すようにシャトルの後部 の ERNO パレットの中に積み込まれる。カメラの制御

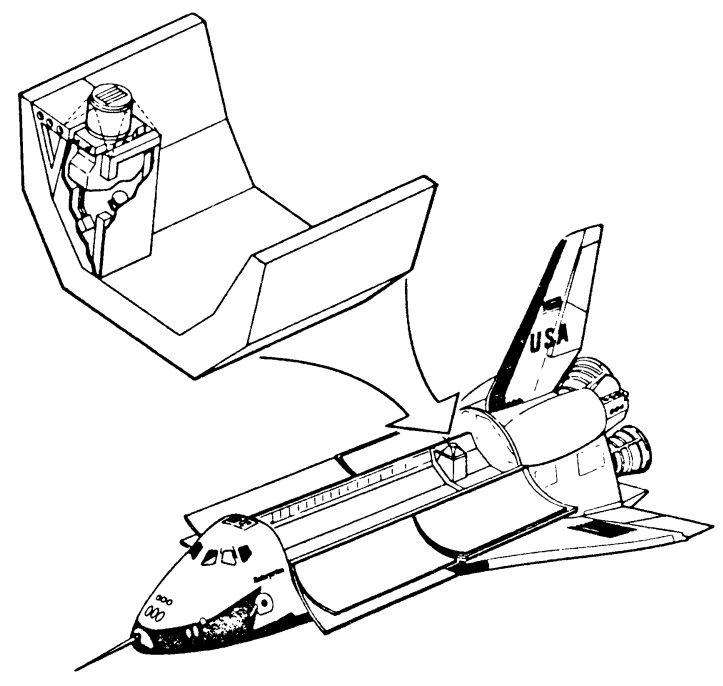

Fig. 9 LFC on Pallet in Cargo Bay

とシャトルのシステムとの関係をいかにするかの研究 がなされた。これによれば，シャトルが地球を視準す る態勢になり，かつ照明条件が良好なときはいつでも 撮影が行われる。船員が雲の被覆状態を見て撮影の停 止をすることができるので，フィルムの節約ができる 利点がある。カメラはシャトルの全搭載重量のほんの 小さな一部であるので, 軌道諸元は, 大きな搭載重量 の機器によって定められてしまう。残念ながら最初の 方のシャトルの飛行の軌道角は小さい值なので, 軌道 にのる期間は 5 日ないし 7 日間だけとなってしまう。 現在の計画では，このカメラは，1980年8月の第 9 回
目のミッションに搭載される予定である。このときの 撮影範囲は, 北緯 $25^{\circ}$ と南緯 $25^{\circ}$ の間に限られる。し たがって, 南アメリカ, アフリカ, 東南アジア, オー ストラリアは撮影されるが，アメリカ，ヨーロッパ， ソビエト，中国は殆ど撮影されない。これより遅いミ ッションの飛行の軌道角は大きな值となっているので, 撮影範囲を広げることができる。図10は，アメリカ合 衆国をカバーするのに最適なミッションを示している。

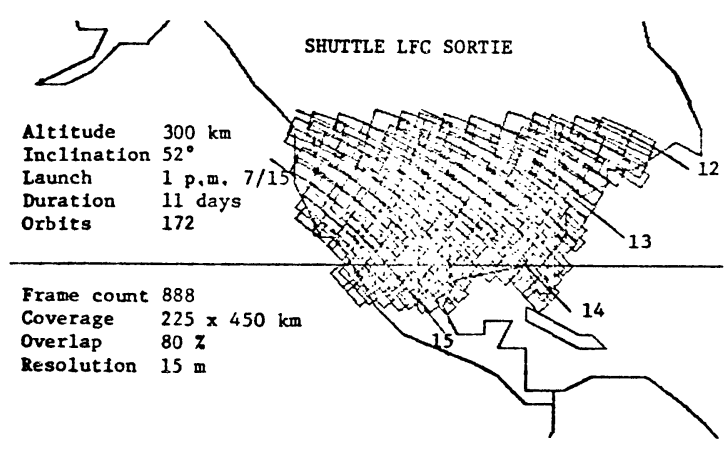

Fig. 10 Optimized US Coverage

短期間で多目的の有人衛星から宇宙写真を撮影する のは効率が良くないことは明らかである。また, 船員 の業務時間, 宇宙船の機能や姿勢掞上び軌道諸元に対 する要求には常に制約がある。この初期の実験ミッシ ヨンから取られた写真が有用であることがわかった場 合には, その後, 自由飛行型の宇宙船にこのカメラが 搭載される。すなわち，シャトルの地上からの打上げ に特殊な設計が施されている多数回利用型宇宙船 (M MS : Multimission Modular Spacecraft) であ る。西部海岸のバンデンベルグ空軍基地のシャトル打 上げ施設が完成する 1983 年には円軌道をとることが 可能となる。このMMSには，1台または 2 台のカメ ラが搭載され，独自の電源，姿勢制御および指令と データ処理システムが備えられる。電源は太陽電池か ら供給される。図11に示されるように, 宇宙船はシャ

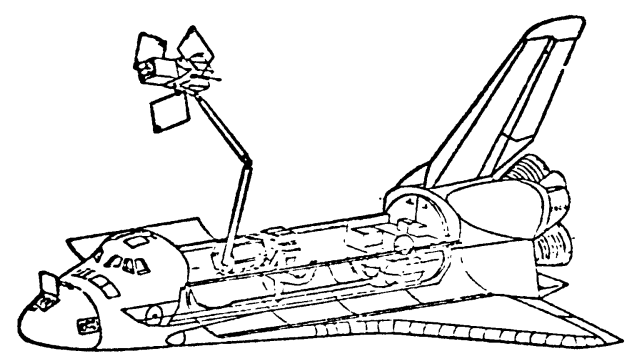

Fig. 11 LFC on Free Flying Spacecraft 


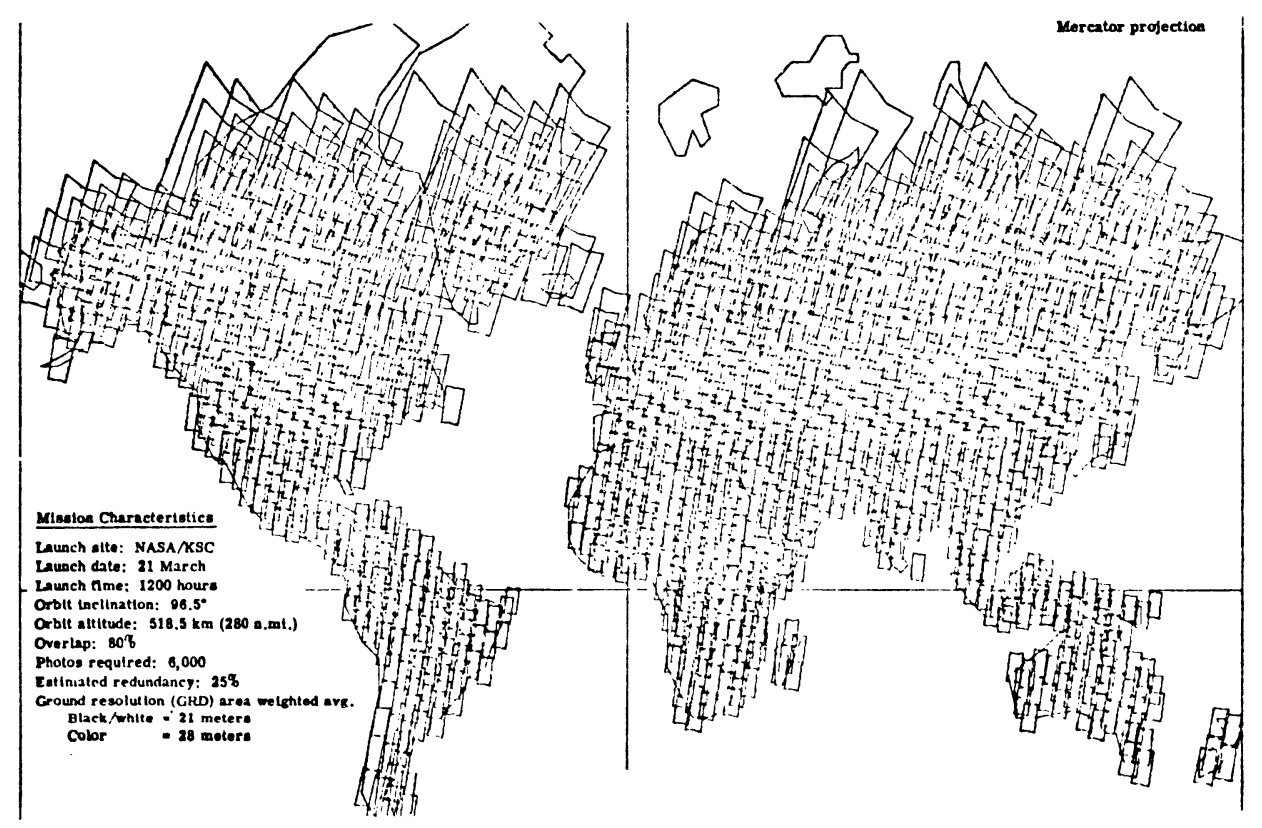

Fig. 12 LFC World-Wide Coverage

トルから出された遠隔操作アームにより支持される。 フィルムが撮影完了すると, MMSはシャトルに引き 寄せられ，宇宙飛行士によりマガジンの交換がなされ る。マガジンが交換された後は再びもとの位置に戻る。 この宇宙船は，定期的に地上に持って帰り，オーバー
ホールの点検をうける。戝 12 は, この宇宙船方式の場 合の撮影範囲を示している。

このシステムが実現すると, 写真測量技術者は, 世 界中の任意の地球の 5 万分の 1 の地形図が作成できる ことになる。(1978.7.26受付) 